Вељко Ж. Брборић ${ }^{1}$

Универзитет у Београду

Филолошки факултет

Катедра за српски језик

https://doi.org/10.18485/mks_knsjkk.2017.ch3

\section{ОБЈАШЊЕЊЕ НЕПОЗНАТИХ РЕЧИ ПРИ ОБРАДИ КЫИЖЕВНОГ ТЕКСТА}

У раду се говори о објашњењу непознатих речи у изучавању књижевних текстова у настави. Наиме, у методичкој литератури се као једна од методичких радњи у настави књижевности редовно наводи и објашњење непознатих

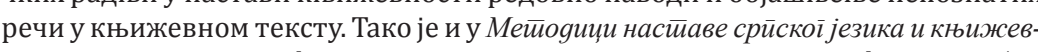
носии $и$ Милије Николића овој методичкој радњи, с правом, посвећена посебна пажња. Није спорно да текстови који се обрађују на наставним часовима (основна и средња школа), без обзира на то да ли се текстови читају у школи (на наставном часу) или изван школе, садрже речи које су ученицима непознате, мало познате и неразумљиве. Свако непознавање неке речи или њено несхватање, делимично или потпуно, отежава пријем књижевног текста. Ово је данас веома актуелан проблем, посебно када се говори о „кризи читања” и о скромном лексичком фонду наших ученика (активном и пасивном). Покушаћемо да, консултујући релевантну литературу, објаснимо шта је овде задатак ученика а шта је задатак наставника на наставним часовима. Консултоваћемо и неке читанке и видети како се у њима приступа овом методичком проблему и да ли су потенцијалне непознате речи објашњене на ваљан начин. Посебно ће бити речи о коришћењу одговарајућих речника српског језика и богаћењу лексичког фонда ученика.

Кључне речи: књижевни текст, непознате речи, методички поступци, активни лексички фонд, пасивни лексички фонд, богаћење лексичког фонда ученика.

\section{1. Увод}

Када се ученици у основној или средњој школи сусрећу сачитањем нових текстова, после читања следи анализа дела на часу, често наилазе и на непознате речи и изразе у конкретном књижевном остварењу. Књижевна дела се читају код куће и у школи, али се увек обрађују на наставном часу и реална је претпоставка

\footnotetext{
${ }^{1}$ brboricv@eunet.rs
}

да се у делу појаве речи које су једном делу ученика непознате или мање познате. Разуме се да то почесто зависи од књижевног дела - има дела која немају превише непознатих речи, али има и оних где је број мање познатих речи веома изражен и то може отежати пријем и разумевање текста и тиме озбиљно утицати на анализу дела. Истина, вреди констатовати да и међу ученицима има велике неуједначености, па иста реч једном делу ученика јесте позната, али има и оних којима је непозната. Активни и пасивни лексички фонд ученика посве је неуједначен и зависи од неколико чинилаца.

Често се дешава да појединци (ученици, али и одрасли) кажу да знају шта желе рећи, шта нам желе објаснити, али да им за то недостају одговарајуће речи, па је и то предмет разних досетки и „проналажење” одговарајуће речи сматра се „малим подвигом”. Лексички фонд ученика директно зависи и од читања књижевних дела.

Неспорна је чињеница да наши ученици на почетку 21. века „беже од читања”, све мање другују с књигом, почесто не читају ни текстове које налаже наставни програм, а читање изван обавезног наставног програма је чешће изузетак, а све мање правило. ${ }^{3}$ Наши ученици, бар нам тако изгледа, не само што мање читају већ и мање разговарају, све више се друже са различитим апаратима (компјутери, мобилни телефони и други технички уређаји) и све то утиче да им је активни лексички фонд све мањи, јер су им главни „сабеседници” технички апарати, па ученици све мање говоре, па комуникација остаје једносмерна.

Методичка поставка је врло јасна, на часовима језика ученици су дужни да овладају језичком нормативистиком (језичком

${ }^{2}$ Тако смо се више пута на усменом испиту из методичких предмета са студентима суочили са чињеницом да и студенти имају овај проблем. Прво не могу да нађу одговарајућу реч, па када им „помогнете” кажу: „то сам и ја мислио/мислила” и друго - приликом писања припрема за наставне часове из књижевности не знају значење неке речи или непознату реч не објасне на најбољи начин. Овакви пропусти и код студената нису ретка појава.

${ }^{3}$ Ово се неупоредиво више односи на средњошколце. Наиме, текстови који се читају у основној школи су неупоредиво краћи и најчешће се читају на часу. У средњо школи се, по правилу, обрађују дела у целини, она су обимнија и читају се, по правилу, код куће. 
правилношћу), на часовима књижевности изучавају све књижевне родове и врсте, тј. целокупни литерарни потенцијал српске и светске књижевности, и све то потврђују усменим и писменим изражавањем, односно културом језичког изражавања. Она је код ученика, врло често, на недопустиво ниском нивоу.

\section{2. објашњење непознатих речи у методичкој литератури}

Овде ћемо урадити увид у методичку литературу и видети шта је задатак предметних наставника и школе, како поступати при објашњењу непознатих речи и израза у књижевном тексту и како поправити лексички фонд наших ученика, односно како да ученици лакше савладају овај проблем у настави књижевности.

У најрелевантнијем методичком приручнику за наш пред-

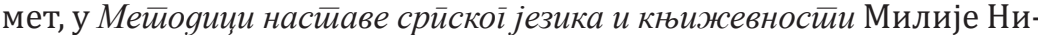
колића, тумачење непознатих речи и израза у тексту помиње се као једна од важних методичких радњи у проучавању књижевних дела (Николић 1992). ${ }^{4}$ Наиме, говорећи о методичким радњама у проучавању књижевних дела, М. Николић каже: „Проучавање књижевних дела у настави обавља се помоћу више саодносних радњи. Свака од њих представља значајну компоненту у целовитом приступу књижевном остварењу" (Николић 1992: 159) и међу двадесет наведених методичких радњи, под бројем седам, налази се тумачење непознатих речи и израза у тексту. 0 овој методичкој радњи се посебно говори на четири стране, а помиње се и на другим местима у књизи (Николић 1992: 214-217). Методичка поставка је више него јасна и констатује да текстови који се користе у настави садрже речи које су ученицима непознате и неразумљиве и да свако несхватање једне речи може бити потпуно или делимично; некада је изражено код појединца, некада реч не разуме део ученика, а може бити да реч не познаје ни цео разред, тј. одељење. Свако несхватање речи отежава пријем и разумевање текста и тако остајемо без могућности за његово потпуно доживљавање, чиме је онемогућено и интерпретирање и ваљана анализа на наставном часу (Николић 1992: 214).

\footnotetext{
${ }^{4}$ Метиоgика Милије Николића имала је више издања (прво издање, 1988) и сматрамо је нашом најбољом методиком. Користи се већ три деценије и биће коришћена и консултована и у деценијама које су пред нама.
}

Милија Николић сматра да се неразумевање неке речи може јавити у три вида: а) реч може бити непозната и по облику и по значењу, б) реч може бити позната, али је непознат појам који је њоме означен и в) може бити познат облик и основно значење речи, али остаје непознат њен смисао у контексту и ово се посебно односи на вишезначне речи и њихову фигуративну употребу. Јасно је да наставник приликом припремања анализе књижевног дела може предвидети неке непознате речи, али то није могуће урадити увек, тј. никада не можете знати која ће реч неком ученику бити непозната. Посебну групу чине архаизми, варваризми, неологизми, провинцијализми и неки термини и сваке од наведених категорија има у делима која се обрађују на наставним часовима. Наши ученици данас, по мишљењу М. Николића, немају у свом лексичком фонду сасвим обичне књижевне изразе и као примере наводи неке као што су: наћве, сйуй $а$, браg-

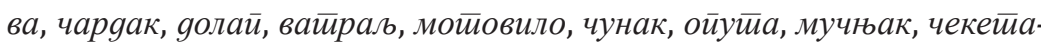

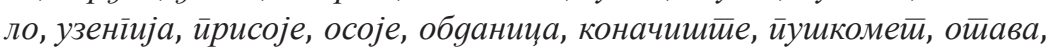
забран, чаир, ирриина... Свакако да је додатан проблем и то што се ученицима непознати појмови означени овим речима и да најчешће изостају и одговарајуће илустрације. Тако се, по тврдњи М. Николића, у одломцима из романа На Дрини ћуйрија „Гуслар” и „Данак у крви” обично тумаче само речи gанак, кулук, сеие $\bar{u}, c y$ харија, сејмени. Међутим, детаљнијом провером је утврђено да појединци, па и групе ученика VII и VIII разреда основне школе не схватају из поменутих одломака следеће речи: киван, баgава,

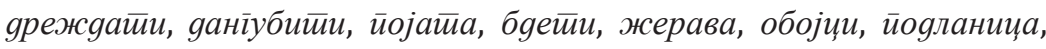

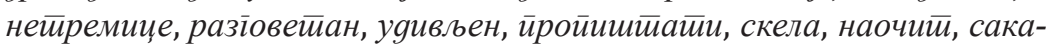

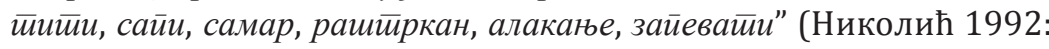
215). ${ }^{5}$

Приступ М. Николића предлаже да наставник у току свога припремања за обраду књижевног дела на наставном часу предвиђа које би речи ученицима могле бити непознате и које речи имају нова, изузетна, пренесена и друга значења. Наставник је ду-

${ }^{5}$ Овде вреди напоменути да се лексички фонд језика непрестано мења и да је ово врло комплексно питање. Данашњим ученицима остаје нејасан велики број речи и израза из народне књижевности, али и из српског реализма. Из ових области наставни програми предвиђају обраду великог броја дела у основној и средњој школи. 
жан и да проналази најбоље начине за тумачење тих речи и да се при томе служи одговарајућим речницима. ${ }^{6}$ Такође се у истраживачко читање може унети захтев да ученици обрате пажњу на непознате речи, да их издвоје или подвуку. Ово се може односити и на оне речи у чија значења ученици нису сигурни. Разуме се да је ученицима најлакше и најфункционалније да објашњење потраже у конкретној књизи уколико такво објашњење постоји. Конкретна књига може бити читанка или одређено дело, али се не може искључити могућност да у њој нема ваљаног објашњења или да објашњење изостаје. Такви случајеви нису ретки. Значење речи могу објашњавати и сами ученици током анализе текста. Реална је претпоставка да има ученика који знају објашњења за оне речи и изразе који су једном делу ученика непознате. Задатак наставника је да такве ученичке одговоре подстиче и по потреби их коригује и допуњује. Овим се подстиче ангажовање бољих ученика, али истовремено пружа могућност оним слабијима да стекну нова знања, настава постаје активнија и мотивишу се додатно ученици који су вредни и имају боља знања, тј. већи лексички фонд.

Постоје и непознате речи које се морају тумачити у контексту, то значи да се реч мора прочитати у реченици у којој је употребљена, како би се избегло погрешно тумачење. М. Николић оставља могућност предметном наставнику да на табли бележи оне речи за које процени да би било корисно да постану саставни део активног речничког фонда ученика, али да то никако не сме бити искључиви захтев. Ту наводи примере из Поварешеше Симе Матавуља и констатује да неке речи ученици неће употребљавати, те да се никако не очекује да буду саставни део њиховог активног лексичког фонда. Њих није потребно памтити изван конкретног дела, већ је довољно кратко усмено образложење. Истина, и овде се ученицима морају објаснити значења тих речи, јер без њиховог разумевања не може се ваљано обрадити и разумети конкретно дело. Постоје и случајеви када је неопходно да предметни настав-

${ }^{6}$ Додатан је проблем што немамо одговарајући школски речник, па се предметни
наставник мора ослонити на конкретно књижевно дело и објашњења која иду уз наставник мора ослонити на конкретно књижевно дело и о
њега и наше основне речнике (једнотомник и шестотомник). ник објасни значење непознатих речи и пре читања текста, посебно када се непознате речи налазе у насловима дела. ${ }^{7}$

Миодраг Павловић у књизи Прийремање настиавника и ученика за йумачење књижевних дела посебно говори о тумачењу непознатих речи, појмова и израза на девет страна, уз навођење конкретних примера (Павловић 2008: 135-144). Он констатује да „Методичка радња тумачења непознатих речи, појмова и израза настоји да ученицима омогући разумевање језика дела како би се доживљај и значење садржаја остваривали у мери неопходној за ваљану интерпретацију" (Павловић 2008: 135). Неспорно је, каже М. Павловић, даученици читањем књижевних дела богате и усавршавају језички фонд и сопствени језички израз и напомиње да је добро код ученика формирати услове за самосталан приступ речницима, лексиконима, селективним речницима, речницима речи страног порекла, појмовницима и енциклопедијама (Павловић 2008: 137).

Павле Илић (1997) и Симеон Маринковић (2003) у ауторским методикама не посвећују посебну пажњу тумачењу непознатих речи и израза. Њих нема ни међу регистрима појмова и то сматрамо озбиљним недостатком ових методичких приручника.

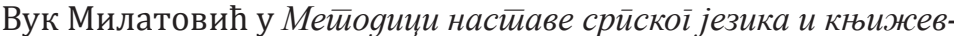

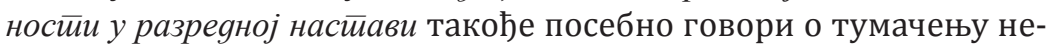

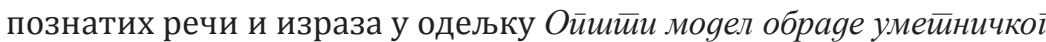

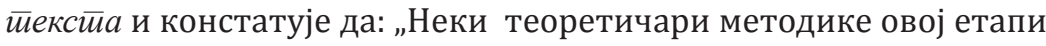
не само да не посвећуjу посебну пажњу него је и заобилазе као непотребну, као нешто што се подразумева само по себи" (Милатовић 2011: 281). Овде налазимо констатацију да непознате речи могу бити стране речи, али и „дијалектизми, локализми, старе речи, кованице, фигуративно употребљене речи итд." В. Милатовић констатује да је непознате речи најбоље тумачити после „тихог усмереног читања”, као и да неке ваља објаснити пре читања текста, а да неке непознате речи вреди записати на табли. Притом додаје да у томе не треба претеривати, тј. да се овоме

${ }^{7}$ Међу такве текстове М. Николић сврстава неколико дела - Notturno, Нирвана, Ha Газиместиану, Астиреа.. 
мора приступати пажљиво. ${ }^{8}$ Ипак, ми сматрамо да је после читања најбоље објаснити само тзв. „кључне речи”, док је целовито објашњење мање познатих речи боље оставити за други део часа, када се говори о језику и стилу књижевног текста.

Посебан проблем представљају дела и текстови који су „(пре)засићени” мање познатим речима и она дела која су обимнија. Овде се проблем никако не може решити на часовима обраде конкретних књижевних дела, јер би за објашњење мање познатих речи и цео наставни час био недовољан. Таквих дела има у наставном програму за средњу школу. Међу оваква дела М. Николић убраја Ивкову славу, Зону Замфирову, Поварейу, Кањоша Маиеgоновића, Госӣоgу Глембајеве, Дуняа Мароја. Свакако да оваквих дела има још и можда је најрепрезентативнији пример Његошевог Горской вијениа. Овде је нужно да се ученицима на време скрене пажња да читају она издања која су намењена управо средњошколцима и која имају ваљана објашњења, тј. издања која су приређена за школу. ${ }^{9}$ Ова издања често имају и предговор или поговор намењен средњошколцима, па је то додатан разлог да њих ученици користе као књигу из које читају дело. И М. Николић закључује да се непознате речи могу тумачити пре читања и после читања, али се ово увек мора радити на квалитетан и одговарајући начин (Николић 1992: 217).

Не можемо а да посебно не констатујемо да дела која имају доста непознатих речи и израза ученици не би смели читати ако немају издање са њиховим добрим објашњењем. Заправо, ученици би тако читали текстове које не би могли доживети и разумети, на час анализе би дошли без добре припреме, додатно би „омрзли” читање, утрошили драгоцено време, а анализа дела не би могла бити успешна.

Овде вреди напоменути да се лексички фонд језика непрестано мења и да је ово нормалан процес. Један део лексичког фонда

${ }^{8}$ Сматрамо да је приступ В. Милатовића оправдан и да учитеље и ученике још у млађим разредима морамо обавезати на ваљан приступ непознатим речима и њиховом ваљаном објашњавању. Чини се да овај поступак у млађим разредима често изостаје и да то додатно слаби лексички фонд наших најмлађих ученика.

${ }^{9}$ Некада су озбиљне издаваче куће имале посебне едиције намењене ученицима основе и средње школе, а данас су таква издања реткост. Тиме су ученици остали без драгоцене помоћи и тиме је настава оштећена. стари, али зато стално у језик долазе нове речи, лексички фонд постаје богатији, али поједине речи и изрази полако нестају. То је само потврда раније изнете тврдње да је данашњим ученицима непознат велики број речи које сусрећу у делима које обрађују у школи, нарочито у оним насталим пре друге половине двадесетога века.

\section{3. Речници у настави и њихово коришћење}

Коришћење речника у настави књижевности важно је методичко питање. Овде можемо говорити о речницима уз књижевна дела која читају наши ученици, али и о речницима српског језика уопште. О коришћењу речника српског језика у настави посебно је говорила Рајна Драгићевић (2012). Она говори о томе како се могу користити речници српског језика, уз напо-

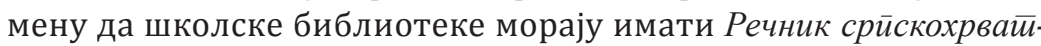
скоі књижевної и нарояної језика Српске академије наука и уметности, али и речнике Матице српске. Посебно због тога што Речник САНУ није завршен, препоручује се коришћење Речника

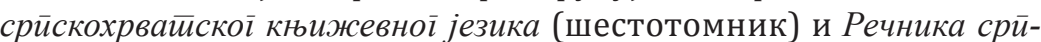
скоі језика (једнотомник). Ученике средње школе можемо упу-

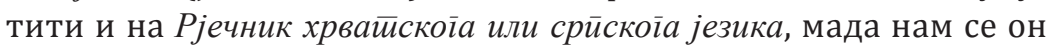
не чини погодним за наставу. Р. Драгићевић овде наводи и специјалне речнике. Нама се чини да су они пре свега намењени наставницима, мада се не искључује могућност да их користе и консултују и ученици, посебно се то односи на наше средњошколце. Овде се наводе фреквенцијски речници српског језика деривациони речници, асоцијативни речници, фразеолошки речници, тематски речници, речници жаргона, етимолошки речници, речници нових и страних речи, али и други деривациони речници (Драгићевић 2012: 84-87). Наравно да су нашим ученицима посебно корисни речници страних речи и свакако се међу њима издвајају Лексикон ситраних речи и израза Милана Вујаклије и Велики речник стираних речи и израза Ивана Клајна и Милана Шипке.

Већ смо констатовали да је посебан проблем што ми немамо одговарајуће школске речнике и то представља озбиљан недос- 
татак наше наставе, односно њене ваљане реализације. ${ }^{10}$ Тако P.

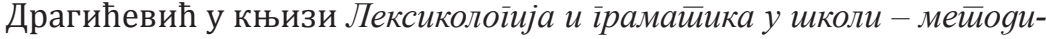
чки оїлеgи у одељку Јеgнојезични речници у настиави срйскої језика констатује: „Због тога је врло важно стално ученике упућивати на језичке приручнике, пре свега на правопис и речнике" (Драгићевић 2012: 75). ${ }^{11}$

Чини се да наши ученици данас највише користе двојезичне речнике, при учењу страних језика, па ми овде нудимо избор једнојезичних речника који би могли наћи место у настави српског језика и књижевности. Ово би био најкраћи избор одговарајућих речника: ${ }^{12}$

А) основни речници:

1. Речник сритскохрвайскоїа књижевной језика, Матица српска - Матица Хрватска, Нови Сад - Загреб, 1967-1976.

2. Речник срӣскохрвайскої књижевної и нарояної језика САНУ 1-18, Београд, 1959-2010. [до речи оцарийи]

3. Речник срйскоїа језика, Матица српска, Нови Сад, 2007. (једнотомни речник)

4. Рјечник хрвайскоїа или срӣскоїа језика, I-XXIII, Загреб, 1880-1976

Б) Међу речницима које било добро да имају школске библиотеке издвајамо:

5. Иван Клајн, Речник нових речи, Нови Сад, 1992.

\footnotetext{
${ }^{10}$ Овакав покушај израде школског речника забележен је у Новом Саду, када су Мирјана Јоцић и Вера Васић објавиле Школски речник сиианяаряної сриескохрвайской хрвайскосрӣской језика (књига прва А-Љ, 1988; књига друга М-По, 1989), али овај пројекат није завршен.

${ }^{11}$ Ово подразумева да имамо одговарајући правописни приручник за основне и средње школе и одговарајући школски речник (школске речнике). Не можемо да не констатујемо да овде имамо озбиљан проблем. Када је посреди правопис, онда морамо рећи да Матица српска од 2010. године, од када је објављено измењено и допуњено издање Правописа, нема одговарајуће школско издање или приручник за школе. Та недостатак унеколико је амортизован Правоииисом срйской језика Милорада Дешића. Већ смо констатовали да немамо одговарајући школски речник, па се ученицима оставља могућност да користе речнике Матице српске (шестотомник и једнотомник).

${ }^{12}$ Верујемо да ће овај проблем бити решен када нашим ученицима буду доступни електронски речници и да ће то бити најбољи начин да их ученици консултују и да тако долазе до ваљаног објашњења непознатих речи и израза.
}

6. Јован Ћирилов, Нови речник нових речи, Београд, 1991.

7. Мирослав Николић, Обрайни речник срӣскоїа језика, Београд, 2002. [најобимнији српски акценатски речник]

8. Јосип Матешић, Фразеолочки речник хрвайскойа или срӣской језика, Загреб, 1982

9. Твртко Прћић, Нови итранскрийциони речник енїлеских личних имена, Нови Сад, 1998.

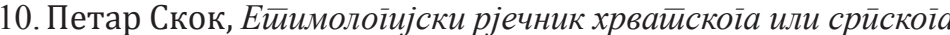
језика, Загреб, 1971-1974.

11. Ейимолошки речник срӣско̄ језика, САНУ и Институт за српски језик САНУ, 1. св. [тек је почео да излази]

12. Миодраг С. Лалевић, Синоними и срояне речи срйскохрвайскоїа језика, Београд, 2004. [фототипско издање]

13. Ранко Јовановић, Лаза Атанацковић, Систиемайски речник срйскохрвайскойа језика, Нови Сад, 1980.

14. Вера Васић, Твртко Прћић, Гордана Негебауер, Речник нових анйлицизама, Нови Сад, 2001.

15. Павле Ћосић (и сарадници), Речник синонима, Београд, 2008

16. Абдулах Шкаљић, Туриизми у срӣскохрвайском језику, Сарајево, 1989. ${ }^{13}$

17. Вук Ст. Караџић, Срйски рјечник, Беч, 1818.

18. Михаило Стевановић (и сарадници), Речник Њеїошева језика I-II, Београд, 1983.

19. Васа Павковић, Речник йоезије Милана Ракића, Нови Сад, 1984.

20.Предраг Пипер, Рајна Драгићевић, Марија Стефановић, Асоиијайивни речник срӣскоїа језика, Београд, 2005.

21. Боривој Герзић и Наташа Герзић, Речник савременої беоіраяскої жаріона, Београд, 2002.

\footnotetext{
13 Ово је врло важан речник, јер је турски језик имао велики утицај на нашу савремену лексику. Тако је тешко претпоставити да ученици следеће речи осећају као турцизме: чаршаф, јасииук, јорі̄ан, сайун, иеешкир, чарайе, йайуче, сандале, чизме, Ђон, јоіурри, чај, кафа, кашика, шећер, кајїана, ииийа, сарма, иииринач, ракија gуван, gуімме, ией, маказе, чекић, ексер, аманети, бакар, боја, бубреї, кајмак, сандук, баклава и др.
} 
В) Нису класични речници, али су одлични и волели бисмо да их користе наставници:

22. Д. Срејовић и А. Цермановић, Речник римске и ірчке митиолойије, Београд, 1979.

23. Дејвид Кристал, Енииклойеgијски речник моgерне линївисииике, Београд, 1988.

24. Дејвид Кристал, Кембричка енциклойеgија језика, Београд, 1987.

Овде долазимо и до приче о томе колико је важна библиотека у настави нашег предмета. Мислимо на личне библиотеке наставника и ученика, али и на школске и градске библиотеке и њихово коришћење у наставне сврхе. Наше је мишљење да би школе поред школских библиотека могле у зборницама имати и приручне библиотеке. Приручна библиотека би била смештена у зборници и она би имала основне речнике. Истина, могла би имати и неке друге књиге. Таква (приручна) библиотека била би лако доступна и сигурно би је користили не само наставници нашег предмета већ и сви наставници и школи. Овакво улагање би се брзо исплатило и сасвим је сигурно да би се тиме поправио и лексички фонд наставника свих предмета. Та приручна библиотека у свом саставу морала би имати поред основних и наведених речника и све важеће уџбенике за наш предмет, неке од постојећих приручника за наш предмет, релевантне граматике и граматичке приручнике за српски језик. Временом би се она могла проширити и другим речницима и књигама, али и одговарајућим енциклопедијама.

Такође је важно да наставници пре читања обимнијег књижевног дела упуте ученике да дело читају из одговарајућег, а не из било ког издања. Немогуће је с разумевањем читати Сремца, Станковића, Његоша, Игњатовића, Лазаревића и многе друге писце ако уз књижевни текст немамо квалитетно објашњење мање познатих речи и израза. Читање дела без одговарајућег речника губи смисао и ученици га не могу ваљано разумети, чиме је анализа знатно отежана.

\section{4. Положај ученика и}

положај наставника при читању дела

Када се ученик приликом читања књижевног дела сусретне са непознатом речју и изразом, он има најчешће три могућности. Прва је да потражи објашњење у конкретној књизи, а то значи да читанка или дело имају речник мање познатих речи. Друга могућност је да консултује неки од постојећих речника, а то значи да користи личну (кућну) библиотеку или да користи школску или неку другу библиотеку. Ова могућност не изгледа баш сасвим реална, али није искључена. Трећа могућност је да објашњење непознате речи добије на часу од предметног наставника, током анализе текста.

Уколико је нека реч непозната предметном наставнику, он нема три могућности, већ само две, тј. да објашњење потражи у конкретној књизи или да користи неку од библиотека (личну, школску, градску). Овде је јасно коју и колику важност имају библиотеке и одговарајући речници. Због тога сматрамо да би успостављање приручних библиотека био одличан посао.

\section{5. Кратак увид у неколико уџбеника}

\section{и објашњења непознатих речи ${ }^{14}$}

Уколико се обрађује краће дело или одломак дела, онда се текст налази у читанкама за одређени разред. Веома је важно да читанке имају објашњења мање познатих речи и то је сада случај са нашим основним уџбеницима. Дешава се да објашњења непознатих речи налазимо одмах уз дело, после књижевног текста или на маргини, уз књижевни текст. Неке читанке имају објашњење и на крају уџбеника. Свако од ових могућности има неке предности, али мислимо да неуједначеност није најсрећније решење. Ипак, најважније је да објашњења буду добра и то за сваку појединачну реч. Због тога смо овде прегледали неке читанке и покушали навести неколико примера када објашњења непознатих речи нису дата на најбољи начин. Ово је посебно важан задатак и за аутора

14 Уџбенике из којих су примери нећемо наводити у списку литературе, на крају рада. Овде је дат пун назив сваке читанке и име аутора, док издавача нисмо наводили. Ови примери су само послужили као илустрација за бољи приступ овом проблему у нашим читанкама. 
и за издавача, не смемо се задовољити половичним решењима, јер и то може лоше утицати на лексички фонд наших ученика. Стога ћемо навести неколико примера у којима непозната реч није објашњена на најбољи начин, односно сматрамо да би објашњење морало бити потпуније. Овде нудимо и она објашњења која се налазе у Речнику срйскоїа језика Матице српске (2007).

У уџбенику чији су аутори Љ. Бајић и 3. Мркаљ, По јуйру се gан йознаје, Чийанка за 5. разреg основне школе, сусрећемо прилично коректно објашњење непознатих речи. Ово је иначе, по нашем мишљењу, квалитетан уџбеник, али при објашњењу речи чакшиpe стоји да је то врсйа йанйалона. Сматрамо да је овде било нужно објаснити и какве су то панталоне. Уз објашњење речи амбар стоји

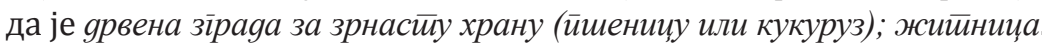
Ако погледамо Речник Матице српске, видећемо да је амбар поред

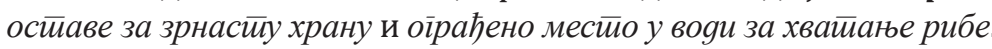

Уџбеник Милке Андрић, Крила илаве иесме, Чийанка за 6. разреg основне школе, објашњава да је бена - неозбиљан човек. Међутим Речник каже да реч бена поред значења неозбиљной човека има значење бygaла, луgа. Ова читанка има објашњење и за три црквена празника: Преображење, Михољуан и рамазан. За Преображење

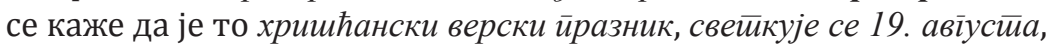
за Михољgан се каже да је верски иразник у окйобру, а за рамазан да је муслимански йосй. Мислимо да је овде понуђена објашњења потребно уједначити и прецизирати.

Тако Речи мудростии - Чийанка за сеgми разреg, коју потписују аутори Зорица Несторовић и Златко Грушановић, има неколико непотпуних и непрецизних објашњења. Ова читанка на неколико места претпостављену непознату реч објашњава другом речју, што не можемо сматрати најбољим поступком. Тако налазимо следећа објашњења: вериїе - ланции, йлоба - иорез, була - суйруїа, gукай - злайник, каяуна - жена. Ипак, права објашњења би била: вериі̄e - 1. ланац над огњиштем; 2. окови, букагије (на ногама затвореника), йлоба - материјална, обично новчана казна и износ те казне; була - 1. муслиманска жена у трад. одећи; 2. округли метални средњовековни печат; 3. задужење у поенима и у игри карата; gукай - златни новац различите вредности; каgуна - угледна, отмена жена, дама (само у муслиманки).
Читанка Ризнииа речи - Читианка за сеgми разреg основне школе Наташе Станковић Шошо нуди и следећа објашњења: блажен срећан; образ - слика; иницијали - иочейна слова имена и ирезимена; йойка-основа. Речник срӣской језика нуди прецизна објашњења и нуди следећа објашњења: блажен - 1. испуњен осећањем највећег задовољства и среће, пресрећан [...]; 4. савршен у верском погледу, свети, који ужива вечиту срећу, благословен; образ - 1. једна страна лица, 2. част, поштење, понос... ; иницијали - велико почетно слово имена или презимена; украсно велико слово на почетку одељка у књизи, старим рукописима; йоика - попречне нити које се уткивају у основу при ткању; 2. фиг. основа, основица.

Као илустрацију навешћемо и примере из две читанке намењене нашим средњошколцима. Прва је Читанка са книжевнойеоријским ӣојмовима за яруіи разред іимназије и среgюих школа Александра Јовановића, у којој уз текст Бакоњ ф рра Брне налазимо следећа објашњења: пура - жїанци, качамак; узенђија - сйре мен; йара - разбој. Уз приповетку Поварей $а$ налазимо да је злић

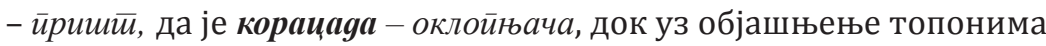
у Његошевом Горском вијениу налазимо да су Трњине - село у Цуцุама, а да су Шииийари - село у Љешанској нахији.

Читианка за йрви разреg іимназија и среgњих стиручних школа Босиљке Милић и Катарине Вучић такође често једну непознату реч објашњава другом речју или кратком синтагмом. Ево неколико примера: касаба - варошица; іррабље - шийражје, ђоїо - кою белаи; каук - чакма; каурин - неверник; броg-їаз; јайлук-марама;

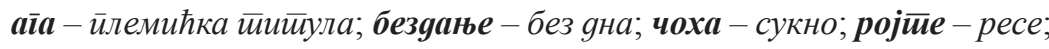

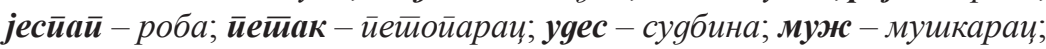
образ - лик, икона, слика и др.

Ови примери неспорно показују да оваква објашњења нису добра решења. Један непознати појам се објашњава другим непознатим појмом. У неким случајевима је објашњење тачно за конкретну употребу неке речи, али то истовремено може ученике одвести у погрешном правцу. Објашњења морају бити боља, прецизнија, јаснија и потпунија. 


\section{6. Уместо закључка}

Објашњење непознатих речи и израза је незаобилазна методичка радња у ваљаном тумачењу књижевних дела. При разговору о језику и стилу неког писца (књижевног дела) увек је добро да се наставник осврне на непознате речи и изразе у тексту, као што је добро да ученицима предочи да речи могу бити једнозначне и вишезначне.

Када затреба, ученицима се могу објаснити и метафора и метонимија, синонимија, антонимија и хомонимија, да им се напомене разлика између домаћих и позајмљених речи, затим да им се објасне шта су историзми, архаизми, дијалектизми, термини и фразеологизми.

Наставник у току свога припремања за обраду текста предвиђа које речи могу бити непознате ученицима, које познате имају нека нова значења и проналази најбоље начине за тумачење служећи се одговарајућим речницима и адекватном литературом.

У упутства за истраживачко читање текста уноси се захтев да ученици обрате пажњу на непознате речи. Наравно, ваља избећи понављање објашњених речи у уџбенику.

Наставник је дужан да допуњује лоша објашњења у постојећој литератури (читанкама и приручницима) и да, када је потребно, упућује ученике на коришћење одговарајућих речника. Ово се посебно односи на средњошколце. Читанке које се користе у настави сада имају пропуста, нека објашњења непознатих речи нису најсрећнија.

Верујемо да би оваквим приступом наставној обради непознатих речи на наставним часовима био побољшан лексички фонд ученика, и активни и пасивни.

Исто тако верујемо да би наставници на овај начин додатно могли мотивисати ученике за читање књижевних дела и да би им то могло додатно „омилити књигу”, а и сами би били оспособљенији за ову методичку радњу.

\section{ЦИТИРАНА ЛИТЕРАТУРА}

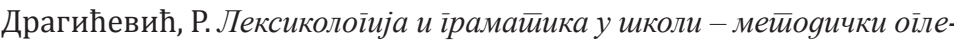
qu. Београд: Учитељски факултет, 2012.

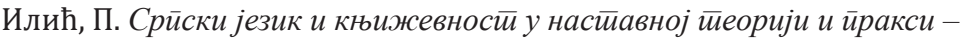

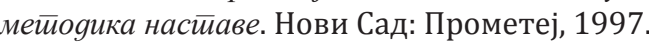

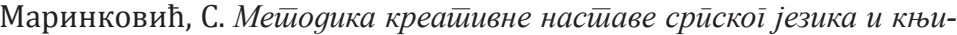
жевностии. Београд: Креативни центар, 2003.

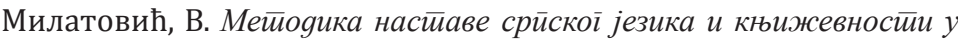
разреgној насйави. Београд: Учитељски факултет, 2011.

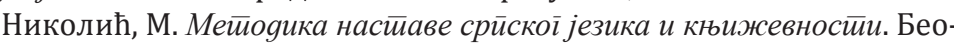
град: Завод за уџбенике и наставна средства, 1992.

Павловић, М. Прииремање насииавника и ученика за ииумачење књижевних gела. Београд: Завод за уџбенике, 2008.

Речник срӣскоїа језика, Нови Сад: Матица српска, 2007.

\section{THE EXPLANATION OF UNKNOWN WORDS DURING INTERPRETATION OF LITERATURE TEXT}

The paper talks about the explanation of unknown words in the study of literary texts in teaching. Namely, in methodical literature, as one of the methodical acts in the teaching of literature, the explanation of unknown words in the literary text is regularly stated. Texts that are interpreted in class (primary and secondary school), whether they are read at school (in class) or out of school, contain words that are unknown to students, little known and incomprehensible. Ignorance and misunderstanding of a word, partially or completely, makes it difficult to receive a literary text. This is a current problem today and it is often said that the lexical fund of our students is scarce. Our classbooks often have omissions and explanations of unknown words are not always the best. In particular, the use of appropriate dictionaries of the Serbian language is discussed, as well as the enrichment of the student's lexical fund and the obligations of the subject teachers. 